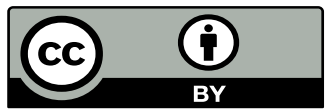

Minna Kaljonen ${ }^{a}$,Taru Peltola ${ }^{b}$, Marita Kettunen $^{c}$, Marja Salod $\&$ Eeva Furman $^{e}$

\title{
Kasvisruokaa kouluun
}

\section{- kokeileva tutkimus ruokavaliomurroksen tukena}

\begin{abstract}
Vegs to school - experimental research for sustainability transition
Mitigation of climate change urges to reduce our meat consumption. This necessitates new eating practices and ways of thinking about food. In this paper we discuss how experimentative research can participate in making such changes. We introduce notions of pragmatic tinkering, speculative thinking and ethical discussion and evaluate their contribution to understanding of change in everyday practices. We investigate their prospects in relation to our experiments with sustainable school dining. In these experiments we introduced a free vegetarian choice to school meals and engaged pupils in their development. The results highlight the dynamic nature of change in everyday practices. The notion of tinkering highlights the small adjustments needed to reconcile the different goals in school dining. Our results stress that the practical adjustments easily uphold the conventional practices. Speculative thinking is needed in challenging them. In our experiments, the engagement of pupils opened places for hesitation, and eventually also to new ways of thinking about school food. The pupils also challenged our experiments. They reminded how eating is entangled to our shared cultural meanings on food, but also to our identity and understandings of gender. In future, experimentative research should build settings, which allow them becoming more multiple as well.
\end{abstract}

\section{Johdanto}

Kasvisruokapäivät aiheuttivat kiivasta keskustelua, kun ne otettiin käyttöön Helsingin kouluissa vuonna 2007 ja puolustusvoimissa vuonna 2018. Niitä kritisoitiin ideologisin perustein tehtynä ja valinnanvapautta rajoittavana "pakkotuputuksena" (Junnilainen 2011; Lombardini \& Lankoski 2013; Miikkulainen ym. 2018). Kritisoijat myös epäilivät saavatko lapset ja nuoret kasvisruoasta riittävästi proteiineja ja muita tarvittavia ravintoaineita.

Suomalaiset käyttävät paljon julkisia ruokapalveluita. Ne tarjoavat meille lämpimän lounaan niin päiväkodeissa, kouluissa, oppilaitoksissa, armeijassa, työpaikoilla kuin vanhusten kotihoidossakin. Suomi on Ruotsin ohella yksi harvoista maista, joka tarjoaa maksuttoman kouluruoan kaikille oppilaille. Tämä velvoite on kirjattu lakiin perusopetuksesta. Sen mukaan kaikille koululaisille on järjestettävä päivittäin tarkoituksenmukaisesti ohjattu, täysipainoinen ateria (Perusopetuslaki 31ฐ).

Kouluruokailu on nähty pitkään keskeisenä terveysvalistuksen ja hyvien ruokailutapojen oppimisen välineenä. Uusimmat ravitsemus- ja kouluruokailusuositukset ohjaavat lisäämään

a. Helsingin yliopisto, Suomen ympäristökeskus, minna.kaljonen@ymparisto.fi,

b. Suomen ympäristökeskus, taru.peltola@ymparisto.fi,

c. Suomen ympäristökeskus, marita.m.kettunen@helsinki.fi,

d. Suomen ympäristökeskus, Helsingin yliopisto, marja.salo@ymparisto.fi,

e. Suomen ympäristökeskus, eeva.furman@ymparisto.fi 
kasvisten käyttöä edelleen (VRN 2014; 2017). Kasvisten syönnin tärkeyttä perustellaan sekä ravitsemuksellisilla että ympäristöllisillä seikoilla. Kasvisruokapäivien lisäksi uudet suositukset ohjaavat kouluja tarjoamaan kasvisruokaa kaikille oppilaille vapaavalintaisena. Ajatuksena on, että tämä houkuttelisi lapsia ja nuoria maistelemaan kasvisruokaa ilman erillistä ilmoitusta. Uudessa opetussuunnitelmassa kouluruokailu nähdään osana kouluissa annettavaa ruokakasvatusta (Opetushallitus 2014). Kouluruokailun aikana ei tulla vain ravituksi, vaan tavoitteena on opettaa hyviä ruokailutapoja ja säännöllinen ruokailurytmi. Uusi opetussuunnitelma korostaa myös koulun kasvatuksellista tehtävää kestävien elämäntapojen oppimisessa. Ravitsemussuositusten mukainen syöminen on nostettu myö keskeiseksi ilmastopoliittiseksi toimenpiteeksi Suomessa (YM 2017).

Kasvisruokapäivistä aina uudelleen käytävä keskustelu osoittaa kuitenkin, että lihan kulutuksen vähentäminen ei ole helppo tehtävä. Luonnonvarakeskuksen ruoan kulutusta mittaavan ravintotaseen mukaan suomalaisten keskimääräinen vuotuinen lihan kulutus per henkilö on noussut 1950-luvun 29 kilogrammasta 81 kilogrammaan lihaa vuonna 2017 (Luonnonvarakeskus 2018). Lihan kulutus on siten noussut lähes $300 \%$ viimeisen 70 vuoden aikana. Huolimatta viime vuosien kasvaneesta kiinnostuksesta kasvisruokaa kohtaan, lihan kokonaiskulutus ei ole lähtenyt laskuun (emt.). Tilastokeskuksen kulutustutkimus on kuitenkin havainnut muutoksia nuorten ruokailutavoissa (Lehto 2018).

Jos ruokavaliomuutoksilla halutaan vähentää kasvihuonekaasupäästöjä, lihan kulutuksen tulisi laskea merkittävästi (Godfray ym. 2010; McMichael ym. 2007; Poore \& Nemecek 2018; Springmann $y m$. 2018). Tämä edellyttää kokonaan uusia ruokailutapoja, käytäntöjä ja ruokaajattelua. Tässä artikkelissa pohdimme, miten tutkimus voi osallistua ruokavaliomurroksen tekemiseen. Arvioimme kokeilevan tutkimuksen mahdollisuuksia ja lähestymistapoja kouluruokailun kehittämisessä. Esittelemme aluksi kolme lähestymistapaa kokeilevaan tutkimukseen ja käytäntöjen kehittämiseen. Tämän jälkeen tarkastelemme tuloksia kestävän kouluruokailun kokeiluista, joissa toimme vapaavalintaisen kasviruoan kolmeen eri kouluun ja osallistimme oppilaat kouluruoan kehittämiseen.

Kokeilumme nostavat esille sen, että kasvisruokailun edistäminen kouluissa vaatii sekä joustavia käytännön ratkaisuja että vallitsevien ajattelutapojen ja käytäntöjen kyseenalaistamista. Johtopäätöksissä korostamme, että kokeileva tutkimus näyttää voimansa etenkin jälkimmäisen kohdalla. Tämä kuitenkin edellyttää avoimuutta ja herkkyyttä myös tutkimukselta. Tutkimuksessa on analysoitava tarkasti, miten kokeiluasetelma joutuu haastetuksi kokeilun aikana. Näin kokeileva tutkimus ei etsi ja tarjoa vain ratkaisuja kestävän syömisen ongelmiin, vaan voi parhaimmillaan tukea siihen liittyvää eettistä keskustelua erilaisista toteutuksen tavoista ja niiden seurauksista.

\section{Kokeilut tutkimuksen ja kehittämisen välineenä: kolme näkökulmaa arjen käytäntöjen moninaisuuteen}

Ilmastonmuutoksen hillinnän myötä kestävän syömisen, liikkumisen ja asumisen kokeilut ovat herättäneet kasvavaa kiinnostusta (Heiskanen \& Matschoss 2016; Hildén ym. 2017; Jalas ym. 2017; Laakso ym. 2017; Schot \& Geels 2008). Kokeilut on nähty dynaamisena tapana kerätä tietoa erilaisten ratkaisujen toimivuudesta käytännössä ja avata arjen innovaatiot yhteiskehittämiselle. Kokeilut on nähty myös muutoksen ajureina. Kysymys siitä, mitä kokeileva tutkimus voi olla - ja miten eri tavoin se voi osallistua muutoksen tekemiseen - on kuitenkin saanut vähemmän huomiota osakseen (Ansell \& Bartenberger 2016; Caniglia ym. 2017; Wittmayer \& Schäpke 2014).

Tässä artikkelissa esittelemämme kolme näkökulmaa kokeilevaan tutkimukseen ovat auttaneet meitä laajentamaan ymmärrystämme kouluruokakokeiluista (Kaljonen ym. 2019). Kaikki näkökulmat pohjautuvat tieteen ja teknologian tutkimukseen tai filosofiaan ja korostavat moninaisuutta arjen käytännöille ominaisena piirteenä. Näillä valinnoilla rajaamme klassisen kokeellisen tutkimuksen pois tarkastelun piiristä. Pohdintamme ammentaa sitä vastoin pragmatismin (Dewey 1927; Marres 2009) perinteestä ja sen käytäntöjen muutosta korostavista näkökulmista. Ammennamme myös kompleksisuusteoriasta (Mol 2002; 2008; 
2010; Law 2004), joka avaa lähestymistapoja todellisuuden moninaisuuteen sekä Alfred North Whiteheadin (1933; Stengers 2010) spekulatiivisesta filosofiasta, joka auttaa meitä jäsentämään kokeilevan ajattelun ja tutkimuksen tapoja. Tavoitteemme on kuvata lähestymistapoja, joiden avulla kokeileva tutkimus voi pysyä avoimena arjen käytäntöjen moninaisuudelle ja auttaa näin tunnistamaan erilaisia mahdollisuuksia tai rajoitteita muutokseen. Tarkastelemme ensin pragmatismin ja kompleksisuusajattelun avulla, miten kokeileva tutkimus voi auttaa tunnistamaan käytäntöihin liittyviä jännitteitä ja ratkaisuja niihin. Tämän jälkeen esittelemme spekulatiivisen lähestymistavan, joka muistuttaa siitä, että kokeilevan tutkimuksen tulisi aina synnyttää myös epäröinnin paikkoja, jotta uutta ajattelua ja ymmärrystä voi syntyä. Epäröinti koskee myös kokeiluja itseään uuden ymmärryksen tuottamisen tapoina. Lopuksi pohdimme, miten kokeileva tutkimus voi tukea eettistä keskustelua itse kokeiluista ja niiden seurauksista.

Hollantilainen terveyden ja hyvinvoinnin tutkija Annemarie Mol on pitkään kehittänyt kompleksisuuteen nojaavaa ymmärrystä tietokäytännöistä, hoivasta ja yhä enemmän myös syömisestä (Mol 2002; 2008; 2010; 2013). Pragmatistiseen arvottamistutkimukseen (Heuts \& Mol 2013) nojaten Mol argumentoi viehättävästi, että hyvä ruoka on aina kompromissi (Mol 2010). Tämä ajatus soveltuu erityisen hyvin kouluruokailun toteutukseen, jossa joudutaan sovittamaan monia ihanteita ja tavoitteita yhteen. Hyvän kouluruoan tulisi olla ravitsevaa ja terveellistä, mutta myös edullista. Uudet kouluruokailusuositukset ja ilmastopolitiikan tavoitteet vaativat edelleen, että kouluruoan pitäisi olla myös ekologisesti kestävää. Hyvä ja kestävä kouluruoka tulee syödyksi, jotta lapset saavat riittävästi energiaa kasvuun ja koulussa jaksamiseen eikä hävikkiä synny. Hyvän ruoan täytyy siis olla myös maistuvaa, mutta rauhallinen ruokaympäristö ja sujuva ruokailutilanne voivat edesauttaa koululounaalle osallistumista.

Mol muistuttaa, että joskus nämä ihanteet voivat elää ja toteutua rintarinnan, mutta useimmiten yhteensovittaminen tuottaa ristiriitoja ja tekee kipeää. Hänen mukaansa ristiriitojen kanssa eläminen ja käytännön ratkaisujen etsiminen on avain muutokseen. Tässä yhteydessä Mol puhuu rukkaamisesta ${ }^{1}$ (tinkering), käytäntöjen korjailusta, säätämisestä ja parantamisesta (Mol 2008; Mol ym. 2010, 13). Hänelle rukkaaminen on nimenomaan kokeilua ja testausta, kompleksisuuden ja epävarmuuden kanssa elämistä ja käytännöllisen järjen käyttöä. Ruoan kohdalla se on myös hyvin materiaalista ja ruumiillista: hyvää ruokaa valmistetaan eri raakaaineita varioimalla, maistelemalla ja houkuttelevasti tarjoten. (ks. myös Koskinen ym. tässä numerossa).

Koska rukkaaminen on luonteeltaan kokeilevaa ja epävarmuuksia ennakoivaa (ks. myös Elmqvist ym. 2018), se tarjoaa näkökulman myös kokeilevaan tutkimukseen. Tunnistamalla ristiriitoja, joita eri ihanteiden yhteensovittaminen tuottaa, tutkimus voi vaikuttaa suoraan käytännön ratkaisujen etsimiseen - ja muutokseen. Näkökulma tarjoaa mielestämme hedelmällisen tavan tarkastella sitä, miten kokeileva tutkimus voi osallistua kasvispainotteisen ruokailun edistämiseen kouluruokailussa. Kouluruokailulla on Suomessa pitkä institutionaalinen historia ja sitä ohjaavat ihanteet ovat vahvasti juurtuneet olemassa oleviin käytäntöihin (Lintukangas 2009; Rückenstein 2012; Wahlen ym. 2012). Kasvispainotteisen ruokailun edistäminen väistämättä aiheuttaa ristiriitoja vakiintuneiden käytäntöjen kanssa. Miten saada lapset syömään uusia ruokia niin, että myös ravitsemusta koskevat tavoitteet täyttyvät? Miten järjestää uudet ruoat linjastolle niin, että ruokailutilanne sujuu edelleen jouhevasti? Miten pitää kustannukset kurissa, kun uudet raaka-aineet ja ruoan valmistustavat vaativat huomiota? Miten tehdä kasvisruoasta houkuttelevaa, kun liharuokiin on totuttu?

Käytännön ratkaisujen löytäminen näihin ristiriitoihin vaatii kompromissien löytämistä ja olemassa olevien käytäntöjen säätämistä ja mukauttamista. Rukkaaminen voi näyttäytyä helposti vain pienten mukauttavien muutosten tekemisenä. Mol kuitenkin painottaa, että ristiriidat ja jännitteet eivät poistu koskaan: käytäntöjä on joka tapauksessa muokattava koko ajan, jotta ne sopivat yhteen. Tämä näkökulma tekee käytäntöjen rukkaamisesta radikaalia. Muutoksen tekeminen vaatii pitkäjänteistä ja pysyvää halua tunnistaa jännitteitä ja löytää niihin ratkaisuja.

1.Vaihtoehtoinen suomenkielinen käännös voisi olla rassata. Rassaamiseen liittyy kuitenkin suomenkielessä vahvempi negatiivinen osaamattomuutta ja näpelöintiä korostava merkitys. Toimimattomat asiat voivat myös rassata, pänniä ja ottaa päähän. Rukata-verbi korostaa vahvemmin käytännön ja parantelun avulla tapahtuvaa asioiden parantamista. Kelloa rukataan ja säädetään, jotta se toimii paremmin. 
Se vaatii käytännöiltä ja niiden toteuttajilta herkkyyttä ja valppautta. Rukkaaminen ei johda muutokseen yhdessä yössä, vaan siinä korostuu jatkuva hereilläolo (Elmqvist ym. 2018).

Jännitteiden tunnistaminen voi auttaa löytämään myös kokonaan uusia ajattelutapoja kasvispainotteiseen syömiseen tai kouluruokailuun. Tämänkaltaisen näkökulman tarjoaa Isabelle Stengers (2010), joka korostaa kokeen tai kokeilujen spekulatiivista luonnetta (ks. myös Gabrys 2014). Stengersin lähtökohta on Alfred North Whiteheadin (1933) spekulatiivisessa tieteenfilosofiassa ja hän painottaa, että hyvä tieteellinen koe on aina sellainen, joka sallii vastarinnan. Vain näin kokeen kohde voi paljastaa todellisen luonteensa kokeen tekijälle. Vastarinta on arvokasta, koska se pakottaa ajattelemaan ja epäröimään. Uuden tiedon ja ymmärryksen syntyminen vaatii aina epäröintiä, Stengers muistuttaa. Hyvän tieteellisen kokeen tulokset ovat aina epävarmoja ja voivat siten avata tilaa epäröinnille ja spekulaatiolle.

Stengers on kehittänyt spekulatiivista ajattelua alun perin jäsentäessään uuden tiedon muodostumista luonnontieteen piirissä, mutta lähestymistapa avaa mielenkiintoisia mahdollisuuksia myös kokeilevaan tutkimukseen yhteiskuntatieteissä. Näkökulma muistuttaa, että itse koeasetelma on tärkeä. Sen avulla voidaan luoda tila, jossa epäröinti — ja siten uudet ajattelun tavat - ovat mahdollisia. Kokeilun avulla eri toimijat voidaan tuoda yhteen niin, että se sallii kasvispainotteista syömistä tai kouluruokailua koskevien ajattelutapojen ja käytäntöjen uudelleen arvioinnin ja parhaimmillaan uudenlaisten ajattelutapojen synnyn. Spekulatiivinen ajattelu laajentaa siten radikaalisti ymmärrystä kokeilevasta tutkimuksesta ja siitä miten se voi osallistua ruokavaliomurroksen tekemiseen. Sen mukaan kokeilut voivat toimia epäröinnin mahdollistavina välineinä, mutta myös osallistumisen tiloina, joissa syntyy uutta ajattelua ja ymmärrystä. Näin ne eivät vain etsi ratkaisuja ongelmiin, vaan voivat toimia myös uudenlaisten, ei-vielä-mahdollisten käytäntöjen ja ajattelumallien syntymispaikkoina (Gabrys 2014).

Politiikan ja teknologian tutkija Noortje Marres (2009) muistuttaa myös, että kokeilu aina väistämättä synnyttää keskustelua kokeilusta itsestään, sen seurauksista ja niihin liittyvistä ongelmista. Kouluruokailun kohdalla tämä voi tarkoittaa kasvispainotteisuutta koskevien tavoitteiden tai niiden edistämistä koskevien tapojen kyseenalaistamista. Kokeilulla voi myös olla arvaamattomia seurauksia, joita tutkija ei ole osannut ennakoida. Marres muistuttaa, että kokeilu- ja tutkimusasetelma on suunniteltava siten, että tämänkaltaiset eettiset kysymykset pääsevät esiin ja ne voidaan ottaa keskustelun kohteeksi (myös Dewey 1927). Kokeiluja kohtaan esitetty kritiikki on arvokasta: se nostaa esiin hankauskohtia, joita murros väistämättä synnyttää (ks. myös Shove $y m$. 2012).

Nämä edellä kuvatut lähestymistavat tarjoavat kolme erilaista näkökulmaa arjen käytäntöjen muutokseen: käytäntöjen rukkaamisen ja mukauttamisen, epäröinnin ja spekuloinnin uusilla vaihtoehtoisilla toimintatavoilla sekä avoimen eettisen keskustelun kokeilujen seurauksista ja hankauskohdista. Seuraavaksi arvioimme miten nämä näkökulmat auttoivat meitä ymmärtämään kasvispainotteisuuden edistämistä, sen mahdollisuuksia ja hankauskohtia kouluruokailussa.

\section{Kestävän kouluruokailun kokeilut}

Toteutimme kasvisruokakokeilut kolmessa suomalaisessa koulussa, joista kaksi sijaitsi maaseudulla ja yksi kaupungissa (Taulukko 1). Suunnittelimme kokeilujen toteutuksen yhdessä koulujen ruokailusta vastaavien ruokapalvelujen ja kotitalousopettajien kanssa. Aloitimme yhteissuunnittelun keväällä 2017 ja etenimme käytännön toteutukseen syksyn 2017 aikana. Kaikki koulut toivat vapaavalintaisen kasvisruoan kouluruokailistoille ja ravintoloihin hieman eri painotuksin ja käytännön ratkaisuin. Koulut saivat siis itse päättää mitä ja miten he asiaa lähestyivät ja kuinka suuria muutoksia olemassa oleviin käytäntöihin he olivat valmiita tekemään. Seurasimme kasvisruokien menekkiä kaikissa kolmessa koulussa lukuvuoden ajan. Tämä on huomattavasti pidempi seuranta-aika kuin kokeiluissa yleensä ja tarjosi arvokasta tietoa myös keittiöille heidän omaa kehittämistyötään varten.

Samalla kun toimme vapaavalintaisen kasvisruoan ruokalistoille, osallistimme myös oppilaat kasvis- ja kouluruoan kehittämiseen. Toteutimme ensin kyselyn, jossa kysyimme oppilaiden halukkuutta valita kasvisruoka lounaalla sekä heidän lempiruokiaan. Kysely toteutettiin heti kokeilun alussa koulujen ruokalassa tableteilla, mikä takasi korkean 
Taulukko I. Kokeilujen yhteissuunnittelu, toteutus ja tutkimusaineisto Table I.The planning of, execution of and empirical material gathered in school food experiments

\begin{tabular}{|c|c|c|c|c|}
\hline & $\begin{array}{l}\text { Maaseutukoulu 1, } \\
\text { (yläkoulu ja lukio } \\
\text { oppilaita n. 500) }\end{array}$ & $\begin{array}{l}\text { Maaseutukoulu } 2 \\
\text { (ala- ja yläkoulu } \\
\text { oppilaita n. 580) }\end{array}$ & $\begin{array}{l}\text { Kaupunkikoulu } \\
\text { (ala- ja yläkoulu } \\
\text { oppilaita n. 670) }\end{array}$ & Kaikki \\
\hline Yhteiskehittäminen & $\begin{array}{l}\text { Useita tapaamisia } \\
\text { ruokapalvelupäällikkö, } \\
\text { keittiön hlökunta, } \\
2 \text { kotitalousopettajaa }\end{array}$ & $\begin{array}{l}\text { Useita tapaamisia } \\
\text { ruokapalvelupäällikkö; } \\
\text { keittiön } \\
\text { ruokapalveluesimies, } \\
3 \text { kotitalousopettajaa, } \\
\text { rehtori }\end{array}$ & $\begin{array}{l}\text { Useita tapaamisia } \\
\text { palvelupäällikkö, } \\
\text { keittiön hlökunta, } \\
1 \text { kotitalousopettaja, } \\
\text { rehtori }\end{array}$ & $\begin{array}{l}\text { 3/2017 } \\
\text { Aloitusseminaari } \\
\text { \& ideointipaja } \\
\text { 3/2018 } \\
\text { Palautepaja }\end{array}$ \\
\hline $\begin{array}{l}\text { Vapaavalintainen } \\
\text { kasvisruoka kouluun }\end{array}$ & $9 / 2017>$ & $8 / 2017>$ & $4 / 2017>$ & \\
\hline $\begin{array}{l}\text { Kasvisruoan menekin } \\
\text { seuranta }\end{array}$ & $9 / 2017-5 / 2018$ & $8 / 2017-5 / 2018$ & $5 / 2017-9 / 2018$ & \\
\hline Oppilaskysely & $\begin{array}{l}9 / 2017 \\
\text { n } 235 \\
\text { vastausprosentti } 47 \%\end{array}$ & $\begin{array}{l}11 / 2017 \\
\text { n } 223 \\
\text { vastausprosentti } 38 \%\end{array}$ & $\begin{array}{l}11 / 2017 \\
\text { n } 356 \\
\text { vastausprosentti } 53 \%\end{array}$ & \\
\hline $\begin{array}{l}\text { Meidän Menu, } \\
\text { kouluruokalista- } \\
\text { suunnittelu ja } \\
\text { ryhmäkeskustelut }\end{array}$ & $\begin{array}{l}8-9 / 2017 \\
1+2 \text { ryhmää } \\
\text { yht. } 33 \text { oppilasta } \\
(7 \text { ja } 9 \mathrm{lk})\end{array}$ & $\begin{array}{l}11 / 2017 \\
6 \text { ryhmää } \\
\text { yht. } 24 \text { oppilasta } \\
(7 \text { ja } 9 \text { lk })\end{array}$ & $\begin{array}{l}11 / 2017 \\
8 \text { ryhmää } \\
\text { yht. } 32 \text { oppilasta } \\
(7 \text { ja } 9 \text { lk) }\end{array}$ & \\
\hline Proteiinivisa & $\begin{array}{l}9 / 2017 \\
\text { useita ryhmiä } \\
\text { yht. n. } 80 \text { oppilasta } \\
(7 \text { ja } 9 \text { lk) }\end{array}$ & $\begin{array}{l}9 / 2017 \\
\text { useita ryhmiä } \\
\text { yht. n. } 150 \text { oppilasta } \\
(7 \mathrm{lk})\end{array}$ & $\begin{array}{l}4 / 2018 \\
\text { useita ryhmiä } \\
\text { yht. n. } 20 \text { oppilasta } \\
\text { (3-6 lk, oppilaskunnan } \\
\text { jäseniä koko kaupungin } \\
\text { alueelta) }\end{array}$ & \\
\hline
\end{tabular}

vastausaktiivisuuden. Esittelimme kyselyjen tulokset koulun oppilaille ja keskustelimme havainnoista tarkemmin valittujen oppilasryhmien kanssa yläkoulun kotitalouden oppitunneilla. Valitsimme oppilasryhmät yhteistyössä kotitalousopettajien kanssa niin, että keskusteluihin ja toimintaan osallistui ryhmiä yläkoulun eri luokka-asteilta. Oppilaat saivat suunnitella viikon kouluruokalistan, Meidän Menun. Tämän toteutustavan keksimme hankaliksi osoittautuneiden ryhmäkeskusteluiden jälkeen, jotka järjestimme ensimmäisessä maaseutukoulussa. Havaitsimme, että oppilaiden kanssa oli vaikea keskustella suoraan ruoasta ryhmissä: keskustelu ei joko lähtenyt liikkeelle tai sitä dominoivat yksittäiset oppilaat. Tästä syystä kehitimme tapoja pohtia kasvispainotteisuutta yhdessä oppilaiden kanssa toiminnallisempien menetelmien avulla (Kaljonen ym. 2018a). Meidän Menu -listojen rakentaminen osoittautui toimivaksi tavaksi osallistaa oppilaita kouluruokailun kehittämiseen verrattuna perinteisiin herkkuruokakyselyihin, koska se kannusti oppilaita pohtimaan yhdessä, miten kouluruokailuun liittyviä eri tavoitteita voidaan yhteen sovittaa ja miten uusia ruokia voidaan tuoda listoille. Tehtävänannon mukaan ruokien piti maistua oppilaille, mutta noudattaa ruokalistasuunnittelun perusperiaatteita. Esimerkiksi kalaa tuli olla tarjolla viikoittain, punaista lihaa korkeintaan kerran viikossa ja jokaiselle päivälle piti olla tarjolla myös kasvisvaihtoehto. Yhteensä 14 pienryhmää suunnittelivat Meidän Menu -listat kahdessa eri koulussa osana yläkoulun kotitaloustunteja. He esittelivät tekemänsä menut myös koulun keittiöhenkilökunnalle. Keittiöt antoivat palautetta listoista ja veivät niistä saatuja ideoita myös ruokalistojen toteutukseen.

Ruokalistasuunnittelun tavoitteena oli tuottaa tietoa oppilaiden näkemyksistä hyvästä kouluruoasta, mutta myös välittää heidän näkemyksiään keittiön henkilökunnalle. Tämän lisäksi järjestimme proteiinivisoja, joiden tarkoituksena oli tutustuttaa oppilaat vaihtoehtoisiin kasvisja hyönteisproteiinin lähteisiin leikkimielisen kilpailun avulla (emt.). Tämä idea syntyi ikään kuin vahingossa, kun toinen maaseutukouluista pyysi meitä järjestämään ohjelmaa paikkakunnalla 
perinteisesti järjestettyyn Leipäpäivä-tapahtumaan. Proteiinivisassa oppilaat saivat ensin maistella erilaisia proteiinin lähteitä: tofua, lupiinitempeä, härkäpapuja sekä kotisirkkoja. Samalla kun oppilaat maistelivat ruokia, kerroimme heille ruokien tuotantotavoista, ympäristövaikutuksista ja ravintoarvoista. Ryhmät saivat lopuksi kisata eri ruokien ilmastovaikutuksista ja proteiinipitoisuuksista.

Nämä kaikki erilaiset osallistamisen tavat tuottivat paljon tietoa ja ymmärrystä siitä, mitä jännitteitä kasvispainotteisen syömisen edistäminen kouluruokailussa aiheuttaa. Me tutkijoina osallistuimme aktiivisesti kokeilujen toteutukseen ja materiaalin keräämiseen. Tässä mielessä tutkimuksemme voi luokitella toimintatutkimukseksi. Kokeilevan tutkimuksen käsitteistö auttaa meitä kuitenkin vahvemmin reflektoimaan sitä, miten luomamme tutkimusasetelmat vaikuttavat kouluruokailun muutospoluista tehtäviin tulkintoihin. Kokeiluja koskeva analyysimme eteni siten nimenomaan tätä kysymystä pohtien. Erittelimme ensin niitä jännitteitä, joita kasvisruoan tuominen kouluruokailuun aiheutti käytäntöjen rukkaamista koskevan käsitteistön avulla. Oppilaiden osallistaminen kouluruokailun kehittämiseen avasi epäröinnin paikkoja, jotka haastoivat sekä meitä että keittiöitä miettimään kokeiluamme ja kasvispainotteisuuden edistämistä kouluruokailussa uusin tavoin. Analyysissamme tunnistimme näitä uudelleen ajattelun siemeniä ja analysoimme myös miten kokeiluasetelmamme joutui haastetuksi.

Olemme antaneet kokeilukumppaneillemme mahdollisuuden antaa palautetta tutkimuksestamme pitkin matkaa. Järjestimme myös koulujen ja ruokapalveluiden kanssa yhteisen palautetilaisuuden kevälllä 2018, jonne kutsuimme myös kansallisen tason toimijoita jakamaan kokemuksia kanssamme. Tilaisuuden tavoitteena oli edistää keskustelua kasvispainotteisen syömisen edistämisen keinoista kouluissa, siihen mahdollisesti liittyvistä ongelmista ja ratkaisuyityksistä. Myös oppilaiden vanhemmat ovat lähettäneet meille palautetta, kun tiedotimme heille kokeilusta ja tutkimushankkeesta. Käytämme näissä eri tilanteissa saatuja palautteita yhtä lailla tutkimusaineistona: ne kertovat paljon kokeilun herättämistä tunteista ja reaktioista. Niiden avulla voimme myös pohtia kokeilujen laajempaa vaikuttavuutta.

\section{Kouluruokakokeilujen avaamat muutospolut}

\section{Käytäntöjä rukkaamalla muovataan vallitsevia käytäntöjä}

Kasvisruoan tuominen vapaavalintaisena ruokalistoille ja ruokasaliin nostatti kaikissa kolmessa koulussa jännitteitä ja ristiriitoja muiden kouluruokaan liittyvien ihanteiden välillä. Ruokapalvelupäälliköt ja ruokapalveluiden henkilökunta lähtivät ratkomaan tavoitteiden välisiä ristiriitoja hyvin käytännönläheisesti. He olivat tässä taitavia: He sovittelevat kouluruokailuun liittyviä erilaisia tavoitteita yhteen päivittäin. He myös halusivat löytää käytännön ratkaisuja, sillä heille kaikille kasvispainotteisuuden edistäminen oli tärkeä asia. Vapaavalintaisen kasvisruoan tulo kouluruokailuun ei kuitenkaan saanut horjuttaa liikaa vallalla olevia käytäntöjä. Keittiössä ruoan laiton oli edelleen tapahduttava jouhevasti ja ruokailutilanteen oli edettävä sujuvasti. Ennen kaikkea lasten on syötävä ruokansa. Uudet tarjotut kasvisruoat eivät myöskään saaneet lisätä hävikkiä.

Vapaavalintaisen kasvisruoan tuominen kouluruokailuun vaati kaikissa kouluissa linjastojen uudelleen järjestelyä. Tämä pieneltä vaikuttava toimenpide nostatti esiin jännitteitä monien vakiintuneiden kouluruokailukäytäntöjen ja tavoitteiden kanssa. Yhdessä maaseutukouluista oli kiinteät linjastot, jolloin toisen ruoan tuominen linjastolle osoittautui erityisen hankalaksi. Linjastolla ei yksinkertaisesti ollut tilaa riittävästi. Ruokien lisääminen linjastolla olisi vaatinut maitoautomaattien siirtämistä toiseen paikkaan. Ruokapalvelupäällikkö ei kuitenkaan halunnut koskea maitoautomaatteihin: se olisi hänen mielestään ollut ravitsemussuositusten ja EU:n koulumaitotuen hengen vastaista. Koulumaitotuki edellyttää, että rasvaton maito on oltava oppilaille helposti saatavilla. Sitä vastoin ruokapalvelupäällikkö teki käytännön kompromissin ja investoi kokonaan uuteen linjastoon. Ruokalaan tarvittiin linjasto myös erityisruokavalioille, jotka olivat olleet epämääräisesti tarjolla ruokalan nurkassa. Uusi linjasto mahdollisti sen, että kasvisruoat ja erityisruokavaliot pystyttiin tarjoilemaan sujuvammin samalta linjastolta. 

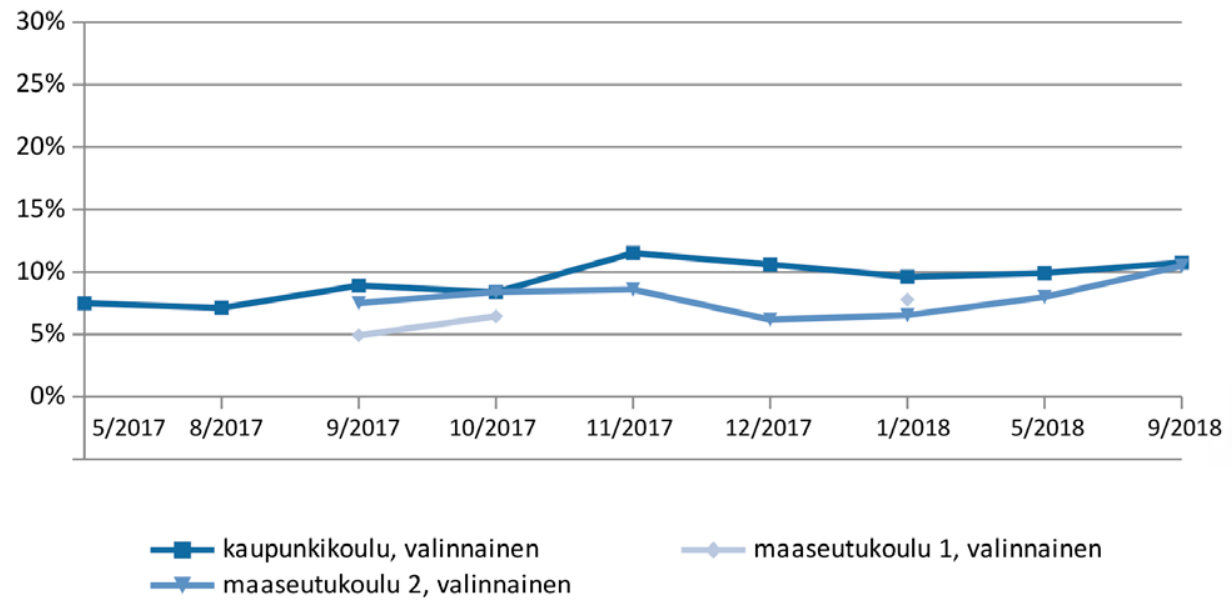

_- maaseutukoulu 1 , valinnainen

Kuva I.Vapaavalintaisen kasvisruoan menekki (osuus kaikista aterioista) kokeilukouluissa Picture I. Share of optional vegetarian meals of all meals consumed at the experimental schools

Linjasto sijoitettiin kuitenkin erilleen muista päälinjastoista, joissa liha- tai kalaruoka oli tarjolla. Tämä kompromissi ei ikävä kyllä auttanut lisäämään oppilaiden kiinnostusta kasvisruokaan. Kasvisruokien menekki säilyi vaatimattomana koko ensimmäisen vuoden ajan, ollen vain noin $5 \%$ kokonaismenekistä (Kuva 1, maaseutukoulu 1). Tehty kompromissi myös vahvisti edelleen käsitystä kasvisruoasta erityisruokavaliona, joka vaatii ravitsemuksellista erityishuomiota.

Toisessa maaseutukoulussa päädyttiin huomattavasti rohkeampaan ratkaisuun. Kasvisruoka päätettiin tarjoilla ensimmäisenä linjastolta. Näin haluttiin houkutella oppilaita valitsemaan kasvispainotteisesti. Linjastomuutos aiheutti kuitenkin niin suuren sekaannuksen oppilaiden keskuudessa, että keittiö perääntyi linjastomuutoksista heti ensimmäisen viikon jälkeen. Kasvisruoka tarjoiltiin edelleen samalta linjastolta, mutta ei enää ensimmäisenä. Tässäkin tapauksessa käytäntöjen rukkaaminen tuotti ratkaisun, jossa kasvispainotteisuuden edistäminen sai väistyä muiden kouluruokailulle asetettujen tavoitteiden tieltä. Ruokailutilanteen on sujuttava jouhevasti, että kaikki kerkeävät syömään. Lasten on myös syötävä lautaselle ottamansa ruoka, muuten lapsi ei saa tarvittavaa määrää ruokaa jaksaakseen ja ruokaa menee hukkaan. Keittiö päätyi ratkaisuun, jossa oli helpompi palata takaisin tuttuun ruokien tarjoilemisen tapaan, kuin lähteä opettamaan oppilaille uusia ruokailukäytäntöjä. Sellainen ei perinteisesti ole kuulunut ruokapalveluiden tehtäviin: tärkeintä on, että oppilaat syövät.

Myös kaupungissa sijaitseva kokeilukoulumme nosti kasvisruoan tarjolle ensimmäiseksi kaikille linjastoille "Ympäristö ja ruoka" -teemaviikon ajaksi. Normaalisti vapaavalintaista kasvisruokaa tarjoillaan yhdellä neljästä linjastosta. Ympäristöviikon aikana koulu kannusti kasvisruoan maisteluun myös muuten. Alakoululaisille järjestettiin uskallusviikko, jonka aikana oppilaat saivat opettajalta tarran aina kun he olivat maistelleet kasvisruokaa (Kaljonen ym. 2018a). Viikon aikana kasvisruoan menekki kasvoi merkittävästi (Kuva 2). Suosio sai koulun oppilaskunnan vaatimaan pysyvää muutosta kasvisruoan tarjoiluun. Keittiö ei kuitenkaan voinut luvata muutosta: se olisi vaatinut mittavia uudistuksia ruoanlaitto- ja tarjoilutavoissa myös keskuskeittiössä, josta ruoat tulevat koululle. He myös pelkäsivät ruokahävikin kasvavan, kun kasvisruokaa pitää olla linjastoilla tarjolla enemmän.

Kokeilukouluissamme ruokapalvelujen henkilökunta pätyi siten hieman erilaisiin käytännön ratkaisuihin rukatessaan ja mukauttaessaan kouluruokailun eri tavoitteita yhteen. Kaikissa käytännön ratkaisuissa kasvispainotteisuuden edistäminen joutui kuitenkin väistymään 


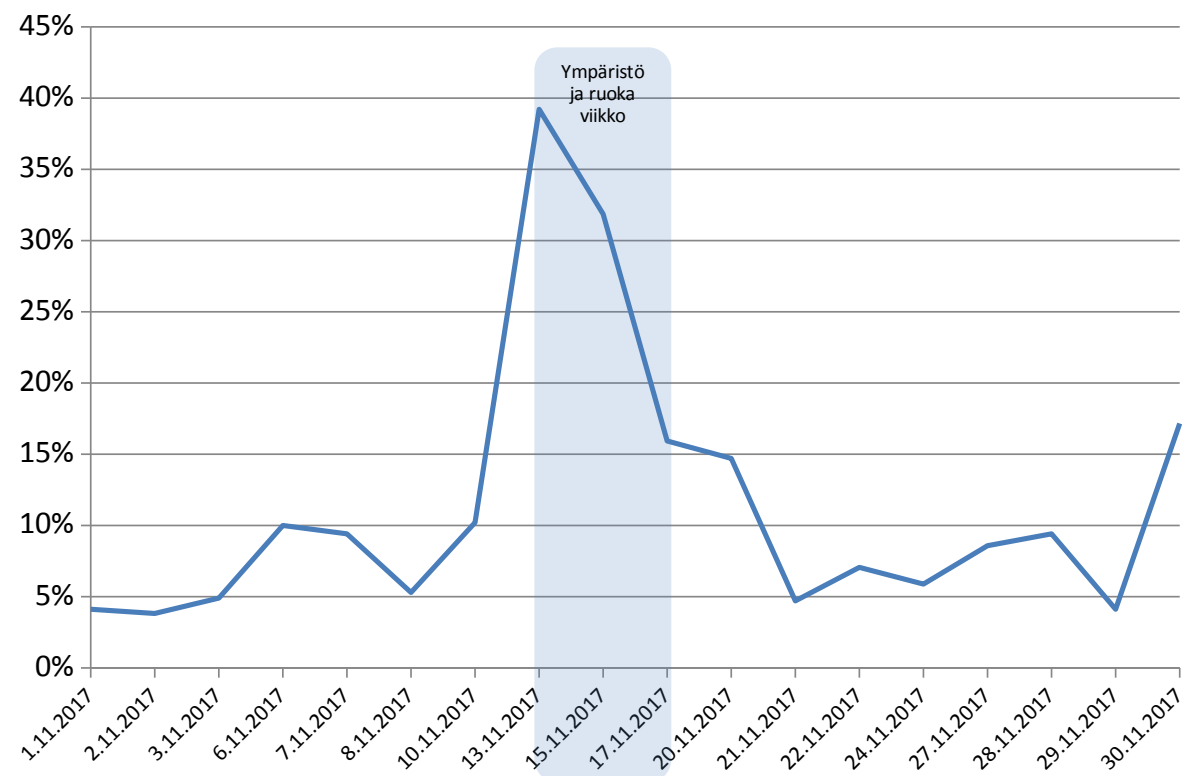

Kuva 2. Vapaavalintaisen kasvisruoan menekki (osuus kaikista aterioista) marraskuussa 2017 kaupunkikoulussa

Picture 2. Share of optional vegetarian meals of all meals consumed during November at the city school

Taulukko 2. Kasvisruokapäivinä tarjoiltuja ruokia kolmessa kokeilukoulussa Table 2.The Vegetarian meals served on Veggie days

\begin{tabular}{|l|l|l|}
\hline Kasvisruokapäivinä tarjotut ruoat, kolme menekiltäan suurinta korostettu \\
\hline kaupunkikoulu & maaseutukoulu 1 & maaseutukoulu 2 \\
\hline Intialainen kasvis-bataattikeitto & Aurinkovuoren makaronilaatikko & Kasvisjauhispyörykät \\
\hline Juuressosekeitto & Härkäpavusta bolognesekastike & Kasvislasagnette \\
\hline Lempeä kasvissosekeitto & Juustoinen kasviskiusaus & Kasvispyörykät \\
\hline Keltainen kesäkeitto & Juusto-kasviskastike & Mannapuuro \\
\hline Mannapuuro & Kasviskiusaus & Ohrasuurimopuuro \\
\hline Ohrarouhepuuro & Kasvis-nuudeliwokki & Perunavelli \\
\hline Pinaattikeitto & Kasvispastavuoka & Pinaattiohukaiset \\
\hline Pinaattiohukaiset & Kasvissosekeitto & Pinaattivelli \\
\hline Riisipuuro & Linssikeitto & Porkkanasosekeitto \\
\hline Tomaattinen lasagnette & Ohrasuurimopuuro, marjakeitto & Riisipuuro \\
\hline & Porkkanaletut & Riisivelli \\
\hline & Porkkanapyörykät+kermavilikastike & \\
\hline & Purjo-perunasosekeitto & \\
\hline & Puuro & \\
\hline & Vehnärouhe-kaurapuuro & \\
\hline & & \\
\hline
\end{tabular}


vakiintuneiden tapojen tieltä, koskivat ne sitten ravitsemusta, ruokailutilanteen sujuvuutta, syömistä, ruoanlaiton organisointia tai ruokahävikin minimointia.

Myös reseptiikkaa oli rukattava. Tämä nousi kokeiluissamme esille toimintana, jossa eri tavoitteita oli sovitettava luovasti yhteen. Uusien kasvisruokien kohdalla reseptit on saatava maistuviksi ja suurkeittiön valmistutapoihin soveltuviksi ja ruokalistat sellaiseksi, että ruoka tulee syödyksi ja on ravitsevaa. Reseptiikkaa kehitellessään ruokapalveluiden henkilökunta oli luovimmillaan, onhan se heidän ydinosaamistaan. Usein he yhdistelivät tuttua ja uutta reseptejä kehitellessään. Yhdessä maaseutukoulussa ruokapalvelupäällikkö korosti, että maitotuotteiden käyttö kasvisruoissa auttaa tekemään kasvisruoista lapsille tuttuja ja maukkaita. Ruokapalvelut tarjoilivat myös kasvisruokapäivinä enemmän tuttuja kasvisruokia - kuten pinaattilettuja, puuroa, kiusausta tai sosekeittoa (Taulukko 2). Näin he pystyivät varmistamaan, että ruoka myös tulee syödyksi. Myös einesten käyttö auttoi, jos kasvisruokareseptiikkaa ei oltu vielä ehditty kehittämään ja testaamaan. Monissa näistä käytännön ratkaisuista uudenlaisten ruokailu- tai ruoanlaittotapojen pitkäjänteinen opettelu sai väistyä syömistä koskevan tavoitteen tieltä. Tärkeää oli kannustaa maistamaan uusia kasvisruokia ja auttaa totuttelemaan niiden makuun. Toisaalta esimerkiksi maitotuotteiden lisääntyvä käyttö ei auta vähentämään ruoan ilmastovaikutuksia.

Toinen rukkaamisen kohde reseptiikassa oli raaka-aineiden alkuperä. Tämä oli tärkeää etenkin maaseutupaikkakunnilla (Alhola \& Kaljonen 2017, 37-40). Kasvisruokareseptiikkaa haluttiin kehittää niin, että esimerkiksi ulkomaisesta soijasta päästäisiin eroon. Toisessa tutkimuksemme maaseutukouluista oli panostettu paljon härkäpapureseptiikan kehittämiseen. Heidän ylpeytensä oli härkäpapurouheesta valmistettu makaronilaatikko, joka oli saanut kunniamaininnan myös kouluruokakilpailussa. Makaronilaatikko myös maistui lapsille ja sitä oli usein tarjolla kasvisruokapäivinä. Myös toisella maaseutupaikkakunnalla kunta oli asettanut viralliset tavoitteet lähiruoan käytölle ruokahankinnoissa. Kokit nimesivät ruokia ruoan alkuperän mukaan. Paikallisen porkkanasoseen käyttö johti kuitenkin ongelmiin reseptiikassa. Sose oli liian karkeaa, eikä keitto oikein maistunut lapsille. Soseen toimittajaa ei kuitenkaan haluttu, tai voitu, vaihtaa lähiruokatavoitteen vuoksi.

Esimerkit korostavat rukkaamista keskeisenä toimintatapana sovitettaessa kouluruokailun tavoitteita yhteen. Jännitteitä tunnistamalla ja yhteen sovittamalla voidaan löytää käytännöllisiä, arkea helpottavia ratkaisuja. Pienet mukautukset käytäntöihin kuitenkin helposti vain ylläpitävät vakiintuneita käytäntöjä. Rukkaamisessa on kuitenkin myös toinen ulottuvuus. Se korostaa muutoksen tekemisen pitkäjänteisyyttä. Lasten on syötävä. Jotta ruoka tulee syödyksi, on sitä koskevat muutokset tehtävä valppaasti ja herkistyen. Jännitteet eivät poistu, vaan niitä on soviteltava koko ajan.

\section{Oppilaiden osallistaminen avasi tilaa epäröinnille ja uusille avauksille: kohti mausteisempaa ja monipuolisempaa kouluruokaa}

Oppilaiden osallistaminen kouluruokailun kehittämiseen valpasti sekä meitä tutkijoita että ruokapalveluiden henkilökuntaa (Kaljonen ym. 2018b). Yläkoulun oppilaat kautta linjan toivoivat mausteisempaa ruokaa — ja olivat toivoneet sitä jo ennen kasvisruokakokeiluja. Järjestämissämme ryhmäkeskusteluissa oppilaat vaativat, että heidän tulisi saada maustaa ruokansa itse ja mausteiden tulisi olla saatavilla ruokasalissa. Kaikissa kokeilukouluissamme tämä ei ollut vielä mahdollista. Oppilaat nostivat myös Meidän Menu -listoille mausteisia ruokalajeja, kuten kasvisnuudeliwokki tai tortillat. Kuvan 3 Meidän Menu -listan luonut poikaryhmä lisäsi pienen pohdinnan jälkeen kasvisnuudeliwokin nimenomaan perjantaille, koska se oli heidän mielestään yksi koulun parhaista kasvisruoista. Meidän Menuissa oppilaat esittivät myös kekseliäästi erilaisia ja totutusta poikkeavia ruokien yhdistelmiä päivän vaihtoehdoiksi.

Oppilailta tulleet ideat saivat yhdessä maaseutukoulussa ruokapalvelupäällikön uudistamaan viestiään kasvisruoasta. Hän ei enää kannustanut valitsemaan kasviruokaa, koska se on kestävää ja terveellistä, vaan koska se on mausteisempi vaihtoehto. "Jos haluat mausteista ruokaa, valitse kasvisruoka", hän kiteytti viestin. Tässä kohden kokeilumme onnistui luomaan tilaa uudelle ymmärrykselle kouluruoasta ja kasvisruoasta osana sitä. Mausteisuutta koskeva avaus vaati 


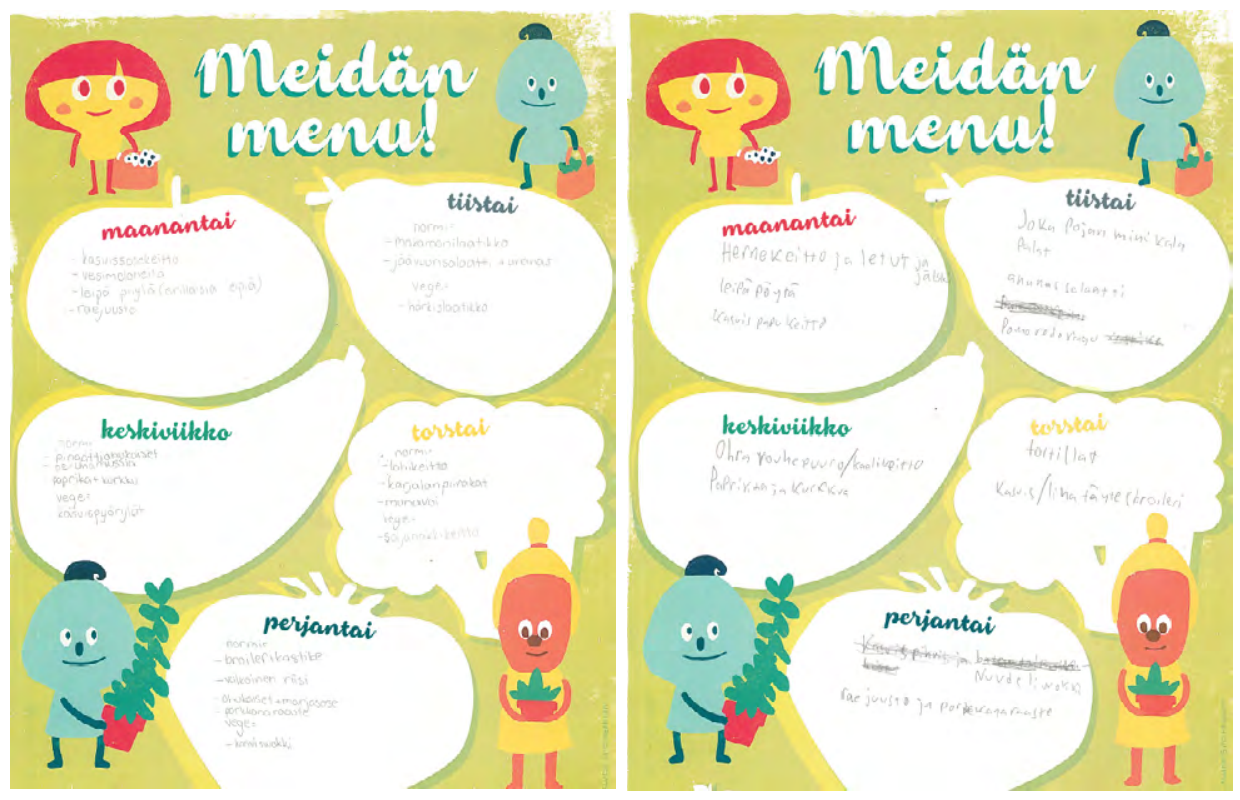

Kuva 3. Kaksi esimerkkiä oppilaiden laatimista Meidän Menu -kouluruokalistoista Picture 3.Two examples of Our Menus designed by the pupils

herkistymistä oppilaiden näkemyksille ja ehdotuksille. Samalla se tarjosi käytännön ratkaisun useampiin kouluruokailun ongelmiin. Kun keittiö voi valmistaa toisen aterian mausteisempana, se voi samalla lisätä oppilaiden osallistumista kouluruokailuun, joka on ollut laskussa etenkin yläkoululaisten keskuudessa (Hoppu ym. 2010; Raulio ym. 2018). Samalla neutraalimpi vaihtoehto on tarjolla edelleen niille, jotka eivät välitä tai ole tottuneet mausteiseen ruokaan. Tämä tukee ruokapalveluhenkilökunnan tavoitteita saada jokainen koululainen syömään lämmin ravitseva ateria. Parhaimmillaan uudet trendikkäät ruokalajit voivat saada oppilaat myös maistelemaan kasvisruokaa ja lisäämään kouluruoan houkuttelevuutta.

Kaupunkikoulussamme ruokapalvelut olivat jo pitkään kehittäneet kasvisruokaa ennakkoluulottomasti. Tämä oli vaatinut pitkäjänteistä kehitystyötä, johon he olivat isona toimijana pystyneet suuntaamaan myös resursseja toisin kuin maaseudun kokeilukouluissa. Monet kaupunkikoulun suosituimmista kasvisruokavaihtoehdoista olivat mausteisia ja uudistavat kouluruokaa rohkeasti (Taulukko 3). Oppilaat onnistuivat yllättämään kuitenkin myös kaupunkikoulun ruokapalvelut Meidän Menu -listoillaan.

Kun yksi 7-luokkalaisten poikaryhmä ehdotti Meidän Menussaan tarjottavaksi sekä mannapuuroa että pinaattilettuja kasvisruokapäivänä, yllättyi listoja kommentoimassa ollut ruokapalvelupäällikkö silminnähden ja sanoi: "Toki voi olla tarjolla kaksi erilaista kasvisruokaa samana päivänä”. Hän itse oli tuskin aiemmin tullut ajatelleeksi vastaavaa, koska kasvisruokapäivien toteutustapa on niin vahvasti juurtunut keittiön käytäntöihin ja ruokalistasuunnitteluun. Samoin hän kehui poikia, kun he olivat laittaneet samalle päivälle tarjolle kalakeiton ja kasvishernekeiton: "Aika jännä yhdistelmä, mutta ei huono -- Tervetuloa ruokalistasuunnittelijaksi töihin meille".

Esimerkit osoittavat, että kokeileva tutkimus voi parhaimmillaan luoda tilanteita, joissa eri toimijoiden väliset näkemykset kohtaavat siten, että ne avaavat uusia ajattelutapoja ja jopa käytännön ratkaisuja. Tässä kohden on korostettava, että puuro ja pinaattiletut ovat edelleen oppilaiden suosikkiruokia koulussa (Taulukko 2; Kuva 3), kuten myös edellä mainittujen poikien. Mausteisemman kouluruoan radikaalius on kuitenkin siinä, että se auttoi sekä oppilaita että ruokapalveluhenkilökuntaa ajattelemaan kasvisruoasta toisin. Ei vain lihattomana 
Taulukko 3. Suosituimmat kasvisruokavaihtoehdot kaupunkikoulussa Table 3. The most popular veggie dishes at the city school

\begin{tabular}{|l|}
\hline $\begin{array}{l}\text { Suosituimmat ruoat vapaavalintaisen } \\
\text { kasvisruoan menekin mukaan }\end{array}$ \\
\hline Soijarouhekastike \\
\hline Appelsiini-quornkastike \\
\hline Soijapyörykkäkastike \\
\hline Punajuuripihvi \\
\hline Kasvisjauhispyörykät \\
\hline Lempeä kasviskeitto \\
\hline Kasvis-falafelpyörykkä \\
\hline Soijamakkara \\
\hline Kasvis-nuudeliwokki \\
\hline Kasvisjauhispyörykät \\
\hline Metsäsienikastike \\
\hline Bataatti-juurespihvi \\
\hline Kasvis-papukroketti \\
\hline Kasvis-kvinoapihvit \\
\hline Quornleike \\
\hline Espanjalainen soijanakkikeitto \\
\hline Sieni-kasvisgratiini \\
\hline Pomodoro Ragu -kasviskastike \\
\hline Soija-paputäyte (tortillaan) \\
\hline Itämainen quornkastike \\
\hline Kullankeltainen kasvis-quornrouhekastike \\
\hline
\end{tabular}

erityisruokavaliona, vaan ruokana, joka voi maistua hyvältä — ja joka voi uudistaa kouluruokailua laajemmin. Meidän Menujen suunnittelu ei siten tarjonnut vain tietoa oppilaiden näkemyksistä kouluruoasta, vaan tilaisuuden kyseenalaistaa kouluruokailuun liittyviä konventioita. Se auttoi oppilaita ja ruokapalveluiden henkilökuntaa ajattelemaan monipuolisemmin kouluruoasta ja kasvisruoasta osana sitä.

\section{Kasvispainotteisuuden kyseenalaistaminen: herkistyminen kokeilujen seurauksille}

Kasvisruoka ja kouluruokakokeilumme joutuivat myös haastatetuksi. "Me tulimme tänne puolustamaan lihaa", joukko poikia sanoi saapuessaan proteiinivisaan, jossa maistatimme kasvis- ja hyönteisproteiineja oppilailla. Vastustus paljasti lihan ja kasvisten syöntiin liittyvät vahvat kulttuuriset merkitykset (Rothberger 2013). Se muistutti meitä myös siitä miten ruokailutapamme rakentavat sosiaalista identiteettiämme (Fischler 1988; Warde 2016). Teiniiässä ruokavalinnat ja identiteetin rakentaminen saattavat kietoutua erityisen vahvasti yhteen. Tämä näkyi ja kuului kokeiluissamme niin, että useimmiten luokan äänekkäimmät pojat asettuivat kasvisruokaa vastaan. Maaseutukoulujen pojat jättivät myös useammin kasvisruoan valitsematta lounaalla (Kuva 4).

Kokeilujen herättämä vastarinta muistutti meitä siitä, että yksin vapaavalintaisen kasvisruoan tuominen kouluruokailuun ei riitä ruokailutapojen pysyvään muutokseen. Kyse on paljon laajemmasta kulttuurisesta murroksesta, johon kietoutuu myös kysymys omasta ja jaetusta identiteetistä itselleen tärkeiden viiteryhmien kesken. Teinipoikien reaktiot kertovat siitä, miten ruokavalinnat linkittyvät kiinteästi myös sukupuoli-identiteettiin. Ruokailutapojen murros vaatii siten muutoksia myös feminiinisyyden ja maskuliinisuuden määrittelyssä (Rothberger 2013). 


\section{Valitsitko kasvisruokaa lounaalla tällä viikolla?}

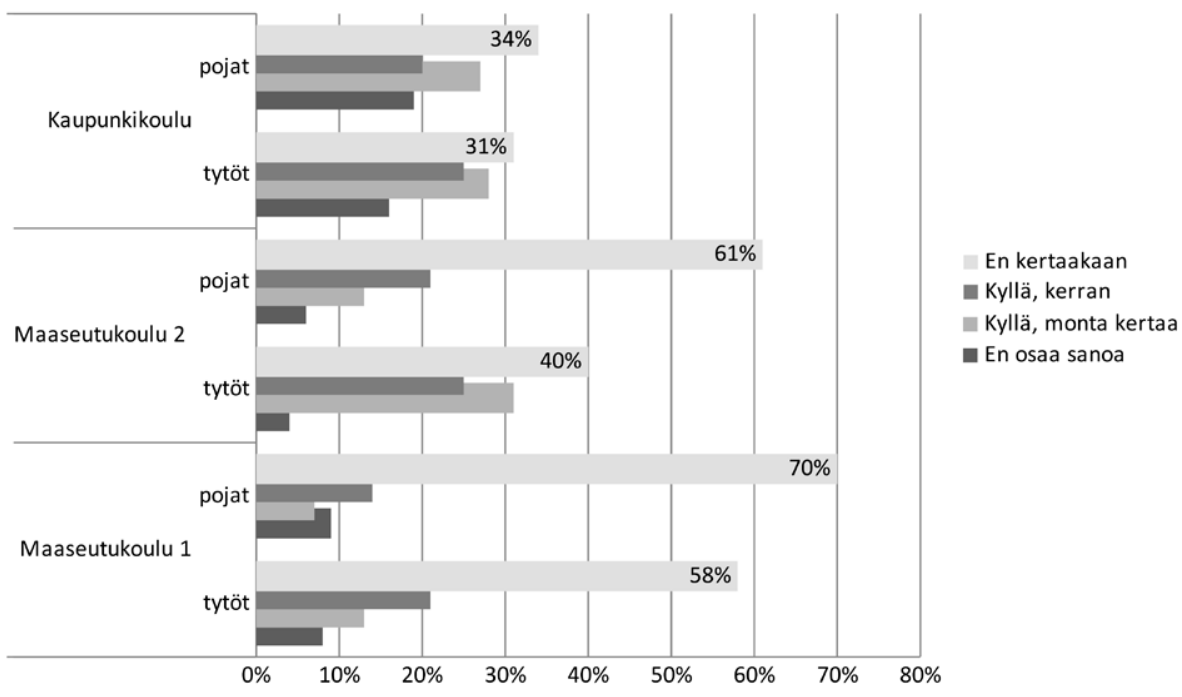

Kuva 4. Valitsitko kasvisruokaa lounaalla tällä viikolla? Kokeilukouluissa tehdyn kyselyn tulokset sukupuolen mukaan

Picture 4. Did you choose the vegetarian option for lunch this week? Survey results from the three schools according to gender

Kokeiluihin osallistuvista kouluista, kaupunkikoulussa erot eri sukupuolten välillä eivät olleet niin merkittäviä (Kuva 4), mikä saattaa kieliä käynnissä olevasta kulttuurisesta muutoksesta.

Jotkut vanhemmat ja opettajat esittivät myös huolensa nuorten syömisestä ja muistuttivat, että teini-iässä nuoret tulkitsevat herkästi ruokaa koskevat valinnat mustavalkoisina. Kasvissyöjäksi ryhtyvä nuori voi myös sekoittaa koko perheen arkirutiinit. Maaseutukoulun kotitalouden ja terveystiedon opettaja oli erityisen huolissaan tyttöjen syömisestä. Hänen mukaansa tytöt saattavat ryhtyä vegaaniksi, kun he haluavat laihduttaa, eivätkä ymmärrä huolehtia riittävästi proteiinin ja muiden ravintoaineiden saannista. Samoin kuin ruokapalveluiden työntekijät, myös hän korosti, että tärkeämpää kuin kasvispainotteisuus on saada nuoret syömään lämmin koululounas päivittäin.

Meihin yhteyttä ottaneet vanhemmat kyseenalaistivat kokeilujen kohdennuksen kasvisruokaan myös sillä perusteella, että tärkeämpää olisi taata ruoassa käytettyjen raaka-aineiden kotimaisuus ja edistää lähiruoan käyttöä ruokapalveluiden hankinnoissa. Toisaalta muutamat opettajat kysyivät myös, miksi emme kokeilujen aikana ole puhuneet eläinten oikeuksista ja hyvinvoinnista vahvemmin. Heidän mielestään eläintuotannon olosuhteiden näyttäminen oppilaille olisi vaikuttavampi tapa edistää kasvispainotteista syömistä.

Kokeiluja vastaan esitetty vastarinta ja esiin nostetut huolet muistuttivat meitä monista eettisistä kysymyksistä, joita syömiseen, ruokaan ja kestävyyteen liittyy. Nämä eettiset kysymykset liittyivät yhtäältä kokeilujen seurauksiin ja toisaalta syömiseen liittyviin arvovalintoihin ja näiden ristiriitoihin. Esiin nostetut huolet ja vastarinta peräänkuuluttavat harkintaa sen suhteen, mihin kestävän syömisen kokeilut kannattaa kohdentaa ja mitä niistä voi seurata. Tulisiko meidän työskennellä nimenomaan poikien kanssa? Ovatko teini-ikäiset ylipäätään oikea kohderyhmä ruokailutapojen murrosta edistettäessä? Entä miten käsitellä kestävää syömistä kokonaisuutena? Kuinka paljon ihmiset ovat valmiita muuttamaan arkista käyttäytymistään? Entä kouluruokailua? Millä tahdilla muutoksia voidaan vaatia? 


\section{Kokeileva tutkimus ruokailumurroksen tukena}

Kokeileva tutkimus voi osallistua ruokavaliomurroksen saavuttamiseen tunnistamalla jännitteitä, jotka vaativat yhteensovittamista ja tukemalla käytännön ratkaisuja, mutta myös luomalla tilanteita, jotka mahdollistavat epäröinnin ja uusien ajattelutapojen luomisen. Kokeilujen herättämä vastarinta auttaa tunnistamaan kasvispainotteisuuden edistämiseen liittyviä rajoitteita ja pohtimaan niiden eettisiä seurauksia.

Kouluruokakokeiluista saadut kokemukset osoittivat, että käytäntöjen mukauttaminen tuottaa helposti vain pieniä, arkeen solahtavia ratkaisuja, jotka ylläpitävät vakiintuneita käytäntöjä. Kokeiluissamme kasvispainotteisuuden edistäminen sai usein väistyä muiden kouluruokailua ohjaavien tavoitteiden tieltä. Ruokapalvelujen tärkein tehtävä on saada lapset syömään ravitsevaa ruokaa. Ruokapalveluiden tuottamat käytännön ratkaisut muistuttavat, että liian suuret yhtäkkiset muutokset ruoissa tai ruokailutilanteessa voivat häiritä tätä tavoitetta. Kouluruokakokeilumme tekivät näkyväksi tämän käytäntöjen rukkaamiseen ja mukauttamiseen liittyvän kaksiulotteisuuden. Ruokavaliomurros vaatii pitkäjänteistä työtä, säätämistä ja arjen valppautta. Riskinä kuitenkin on, että ratkaisut etsitään liian läheltä.

Uusien kestävien ruokailutapojen oppiminen ja juurruttaminen vaatii myös toisin ajattelua. Parhaimmillaan kokeilumme loivat epäröinnin paikkoja, jotka synnyttivät uusia tapoja ajatella kouluruoasta ja kasvisruoasta osana sitä. Tämä vaati oppilaiden osallisuuden vahvistamista kouluruokailun kehittämisessä (Ks. myös Talvia \& Tuijula, painossa 2018). Oppilaiden, ruokapalveluhenkilökunnan, opettajien ja meidän tutkijoiden kohtaamisista syntyi ajatus kasvisruoasta mausteisempana vaihtoehtona. Tämä käytännön ratkaisu mukautti yhteen useampia kouluruokailun tavoitteita. Oppilaiden osallistuminen kouluruokailuun voi lisääntyä, jos tarjolla on useampi erilainen ruokavaihtoehto. Yhteinen ajatteluprosessi loi myös uudenlaisen näkökulman ravitsemukseen: kasvisruoka ei ole vain terveellistä, vaan se voi olla myös maukasta. Kasvispainotteisen ruokailun kokeilua voi siten pitää radikaalina, koska se onnistui tuomaan useamman kouluruokailua koskevan tavoitteen yhteen niin, että syntyi täysin uutta ajattelua. Erityisesti kokeilun osallisuutta vahvistavat elementit auttoivat oppilaita, ruokapalveluhenkilökuntaa ja opettajia ajattelemaan kasvisruoasta uusin tavoin: kasvisruoka voikin monipuolistaa kouluruokailua.

Tämä uusi ajattelu on spekulatiivista siinä mielessä, että se on avannut uuden mahdollisuuksien horisontin, mutta se ei välttämättä takaa että oppilaiden syöminen tai kasvisruoan menekki kasvaisivat. Uuden ajattelun synnyttäminen vaati oppilaiden näkemysten herkempää kuuntelua. Oppilaat myös haastoivat kokeilumme. Oppilaiden ja etenkin yläkoululaisten poikien osoittama kritiikki kasvisruokaa kohtaan paljastaa, miten merkittävä sija lihalla on ruokakulttuurissamme. Vapaavalintaisen kasvisruoan tuominen kouluruokailuun ei auta, elleivät lihaan ja kasviksiin liittyvät kulttuuriset merkitykset muutu samalla (ks. myös Shove ym. 2012; Warde 2016). Kokeilumme nostivat äänekkäästi esiin sen, että kasvisruoan lisääminen — ja siten ilmastopolitiikan toteuttaminen — vaatii muutoksia myös maskuliinisuuden ja feminiinisyyden määrittelyssä. Kaupunki- ja maaseutukoulujen erot olivat tässä suhteessa merkille pantavat.

\section{Johtopäätökset}

Ruokavaliomurros tarvitsee tuekseen sekä pitkäjänteistä puurtamista, käytäntöjen rukkaamista, mutta myös uusia avauksia, jotka kyseenalaistavat totutut toimintatavat. Kokeilumme, joissa toimme vapaavalintaisen kasvisruoan kouluruokailuun, havainnollistavat tätä arkisten käytäntöjen muutokseen liittyvää dynamiikkaa. Kouluruokailukokeiluissa oppilaiden vahvempi osallistuminen kasvispainotteisuuden pohdintaan avasi monia luutuneita toimintatapoja kouluruokailussa. Se pysäytti epäröimään ja synnytti uuden toimintatavan siemenen. Tässä uudessa ajattelutavassa kasvisruokailu ei enää olisikaan vain se terveellinen tai ympäristöystävällinen erityisruokavalio vaan tasavertainen ruoka, joka voi monipuolistaa kouluruokailua. 
Yläkoulun oppilaiden esittämä vastarinta kokeilujamme kohtaan nostaa esille myös eettisen keskustelun tärkeyden. Eettiset näkökulmat kohdentuvat kokeilujen seurauksiin, esimerkiksi mitä perheissä tapahtuu niiden seurauksena, mutta myös siihen, millä tavalla ne oikeuttavat tai haastavat sen suhteen tehtäviä valintoja. Kun puhumme ruoasta, puhumme aina kulttuurisista malleista. Tämä tulee jatkossa huomioida paremmin kokeiluja kohdennettaessa ja kasvispainotteisuutta edistettäessä. Parhaimmillaan kokeilut voivat tukea monipuolisempien, sallivampien kulttuuristen toimintamallien, esimerkiksi sukupuoliroolien etsintää. Ne voivat luoda paikkoja, joissa uusilla vaihtoehtoisilla merkityksillä voidaan leikitellä ja joissa niitä voidaan testata. Uusien merkitysten ja toimintatapojen juurruttaminen vaatii sitten taas käytäntöjen rukkaamista ja pitkäjänteistä kehittämistä.

Oppeja erilaisista käytännön ratkaisuista kasvispainotteisuuden tukemiseksi on jaettava aktiivisesti. Vain näin tehdyt kokeilut, tai kokeileva tutkimus, voi auttaa muuttamaan kulttuurisia merkityksiä ja käytäntöjä laajemmin. Syksyllä 2018 käyty keskustelu puolustusvoimien kasvisruokapäivistä osoittaa, että tätä keskustelua ja oppien jakamista on käyty aivan liian vähän. Vuonna 2018 käytetyt argumentit erosivat vain vähän vuonna 2007 esitetyistä kasvisruokapäiviä kritisoivista argumenteista. Näin silti vaikka käytäntöjä on rukattu ja muutoksia ruokavaliossa ja koulujen ruokalistoilla on tehty kymmenen vuoden ajan.

\section{Kiitokset}

Kiitos Asikkalan tukipalveluille ja Vääksyn yhteiskoululle, Jyväskylän kaupungin Kylän Kattaukselle ja Mankolan koululle sekä Liperin ruokapalveluille ja Liperin koululle yhteistyöstä kokeilujen toteutuksessa ja suunnittelussa. Erityiskiitos kokeiluihin osallistuneille oppilaille kaikissa kolmessa koulussa. Kiitämme myös kaikkia kouluruokailukokeilujen palautepajaan osallistuneita tahoja kouluruokailun kehittämistä koskevasta avoimesta asenteesta. Saimme myös arvokasta palautetta kahdelta käsikirjoituksen arvioineelta tutkijalta, kiitos siitä. Tutkimusta on rahoittanut Suomen Akatemia (296884).

\section{Lähteet}

Alhola, K., Kaljonen, M. (2017) Kestävätjulkiset hankinnat-nykytila ja kehittämisehdotuksia. Suomen ympäristökeskuksen raportteja 32/2017. Suomen ympäristökeskus, Helsinki.

Ansell, C.K., Bartenberger, M., 2016. Varieties of experimentalism. Ecological Economics 130 64-73. https://doi. org/10.1016/j.ecolecon.2016.05.016

Caniglia, G., Schäpke, N., Lang, D.J., Abson, D.J., Luederitz, C., Wiek, A., Laubichler, M.D., Gralla, F. \& von Wehrden, H. (2017) Experiments and evidence in sustainability science: A typology. Journal of Cleaner Production 169 39-47. https://doi.org/10.1016/j.jclepro.2017.05.164

Dewey, J. (1927) The Public and its problems. Southern Illinois University Press, Carbondale Illinois, USA.

Fischler, C. (1988) Food, self and identity. Information (International Social Science Council) 27 275-292. https://doi.org/10.1177/053901888027002005

Gabrys, J. (2014) A Cosmopolitics of Energy: Diverging Materialities and Hesitating Practices. Environment and Planning A 46 2095-2109. https://doi.org/10.1068/a468

Godfray, H.C.J., Beddington, J.R., Crute, I.R., Haddad, L., Lawrence, D., Muir, J.F., Pretty, J., Robinson, S., Thomas, S.M. \& Toulmin, C. (2010) Food Security: The Challenge of Feeding 9 Billion People. Science 327 812-818. https://doi.org/10.1126/science.1185383

Elmqvist, T., Siri, J., Andersson, E., Anderson, P., Bai, X., Das, P.K., Gatere, T., Gonzalez, A., Goodness, J., Handel, S.N., Hermansson Török, E., Kavonic, J., Kronenberg, J., Lindgren, E. \& Maddox, D. (2018) Urban tinkering. Sustainability Science https://doi.org/10.1007/s11625-018-0611-0

Heiskanen, E. \& Matschoss, K. (2016) Paikallisten ilmastokokeilujen arvioimisen haasteet. Alue \& Ympäristö 45 45-58. https://aluejaymparisto.journal.fi/article/view/64899

Heuts, F. \& Mol, A. (2013) What Is a Good Tomato? A Case of Valuing in Practice. Valuation Studies 1 125-146. https://doi.org/10.3384/vs.2001-5992.1312125

Hildén, M., Jordan, A. \& Huitema, D. (2017) Special issue on experimentation for climate change solutions editorial: The search for climate change and sustainability solutions - The promise and the pitfalls of experimentation. Journal of Cleaner Production 169 1-7. https://doi.org/10.1016/j.jclepro.2017.09.019

Hoppu, U., Lehtisalo, J., Tapanainen, H. \& Pietinen, P. (2010) Dietary habits and nutrient intake of Finnish adolescents. Public Health Nutrition 13 965-972. https://doi.org/10.1017/S1368980010001175 
Jalas, M., Hyysalo, S., Heiskanen, E., Lovio, R., Nissinen, A., Mattinen, M., Rinkinen, J., Juntunen, J.K., Tainio, P. \& Nissilä, H. (2017) Everyday experimentation in energy transition: A practice-theoretical view. Journal of Cleaner Production 169 77-84. https://doi.org/10.1016/j.jclepro.2017.03.034

Junnilainen, L. (2011) Lihan syömisen oikeudesta - Miksi kaupunginvaltuutetut rïtelevät kasvisruokapäivästä? Helsingin yliopisto, Valtiotieteellinen tiedekunta, Sosiaalitieteiden laitos.

Kaljonen M., Kettunen, M., Peltola, T. \& Salo, M. (2018a) Kasvisruoka avaa uusia ovia ruokakasvatukselle. Kotitalouslebti 17.5.2018. <https://mmw.kotitalouslehti.fi/kasvisruoka-avaa-uusia-ovia-ruokakasvatukselle/>

Kaljonen, M., Peltola, T. \& Ahponen, H. (2018b) Kasvisruoka voi monipuolistaa kouluruokailua. Editointi Konsta Hellsten. SYKE Youtube 6.9.2018. <https:/ / www.youtube.com/ watch? $v=1 \mathrm{VrDgR}$ A AjwI>

Kaljonen, M., Peltola, T., Salo, M. \& Furman, E. (2019) Attentive, speculative experimental research for sustainability transitions: An exploration in sustainable eating. Journal of Cleaner Production 206 365-373. https://doi. org/10.1016/j.jclepro.2018.09.206

Laakso, S., Berg, A. \& Annala, M. (2017) Dynamics of experimental governance: A meta-study of functions and uses of climate governance experiments. Journal of Cleaner Production 169, 8-16. https://doi.org/10.1016/j. jclepro.2017.04.140

Law, J. (2004) After Method: Mess in Social Science Research. Routledge, London.

Lehto, J. (2018) Lihasta luovutaan pikkuhiljaa - myös muualla kuin pääkaupunkiseudulla. Tieto \& Trendit, Asiantuntijaartikekelit ja ajankobtaisblogit. Tilastokeskus, Helsinki.

Lintukangas, S. (2009) Kouluruokailuhenkilöstä matkalla kasvattajaksi. Kotitalous-ja käsityötieteiden laitoksen julkaisuja 20. Helsingin yliopisto, Helsinki.

Lombardini, C. \& Lankoski, L. (2013) Forced Choice Restriction in Promoting Sustainable Food Consumption: Intended and Unintended Effects of the Mandatory Vegetarian Day in Helsinki Schools. Journal of Consumer Policy 36 159-178. https://doi.org/10.1007/s10603-013-9221-5

Luonnonvarakeskus (2018) Ravintotase 2017 ennakko ja 2016 lopulliset tiedot. < bttps://stat.luke.fi/ ravintotase-2017ennakeko-ja-2016-lopulliset-tiedot_fi>

Marres, N. (2009) Testing Powers of Engagement: Green Living Experiments, the Ontological Turn and the Undoability of Involvement. European Journal of Social Theory 12 117-133. https://doi.org/10.1177/1368431008099647

McMichael, A.J., Powles, J.W., Butler, C.D. \& Uauy, R. (2007) Food, livestock production, energy, climate change, and health. The Lancet 370 1253-1263. https://doi.org/10.1016/S0140-6736(07)61256-2

Mol, A. (2002) The Body Multiple: Ontology in Medical Practice. Duke University Press, Durham and London.

Mol, A. (2008) The logic of care. Health and the problem of patient choice. Routledge, London, New York.

Mol, A. (2010) Care and its values. Good food in the nursing home. In Mol, A., Moser, I \& Pols J. (ed.). Care in Practice. On Tinkering in Clinics, Homes and Farms, 215-234. Transcript, Bielefeld.

Mol, A. (2013) Mind your plate! The ontonorms of Dutch dieting. Social Studies of Science 43 379-396. https://doi. org $/ 10.1177 / 0306312712456948$

Mol, A., Moser, I. \& Pols, J. (2010) Care in Practice: On Tinkering in Clinics, Homes and Farms. Transcript Verlag, Bielefeld.

Opetushallitus (2014) Perusopetuksen opetussuunnitelman perusteet. Määräykset ja ohjeet 2014:6. Opetushallitus, Helsinki.

Perusopetuslaki 31ऽ (13.6.203/1136)

Poore, J. \& Nemecek, T. (2018) Reducing food's environmental impacts through producers and consumers. Science 360(6392) 987.

Raulio, S., Tapanainen, H., Nelimarkka, K., Kuusipalo, H. \& Virtanen, S. (2018) Kundes- ja kahdeksashokkealaisten ruoankäyttö: Koulujakelujärjestelmätuen alkukartoitus. Työpaperi 25/2018. Terveyden ja hyvinvoinninlaitos, Helsinki.

Rothberger, H. (2013) Real men don't eat (vegetable) quiche: Masculinity and the justification of meat consumption. Psychology of Men \& Masculinity 14 363-375. http://dx.doi.org/10.1037/a0030379

Rückenstein, M. (2012) Kouluruokailun vaikuttajat. Kansalaiskasvatuksesta kulutuskultttuuriin. In Pekkarinen, E., Vehkalahti, K. \& Myllyniemi, S. (ed.) Lapset Ja Nuoret Instituutioiden Kehyksissä. Nuorten Elinolot -- Vuosikirja 2012. Nuorisotutkimusseura Julkaisuja 131, 156-169. Nuorisotutkimusverkosto, Terveyden ja hyvinvoinnin laitos, Valtion nuorisoasiain neuvottelukunta, Helsinki.

Schot, J. \& Geels, F.W. (2008) Strategic niche management and sustainable innovation journeys: theory, findings, research agenda, and policy. Technology Analysis \& Strategic Management 20 537-554. https://doi. org/10.1080/09537320802292651

Shove, E., Pantzar, M. \& Watson, M. (2012) The dynamics of social practice. Everyday life and how it changes. Sage, London.

Springmann, M., Clark, M., Mason-D’Croz, D., Wiebe, K., Bodirsky, B. L., Lassaletta, L., ... \& Jonell, M. (2018) Options for keeping the food system within environmental limits. Nature 562(7728) 519-525. https://doi. org/10.1038/s41586-018-0594-0

Stengers, I. (2010) Including nonhumans in political theory: Opening Pandora's box? In Braun, B \& Whatmore, S. (ed.) Political Matter. Tecbnoscience, Democracy, and Public Life. 3-34. University of Minnesota Press, Minneapolis.

Talvia, S. \& Tuijula T. (2018) Lautasen tuolta puolen: alakoululaisten kouluruokailudiskrussit ja kouluruokailun kehittämiseen heijastuvat jännitteet. In Risto R., Haltia, N. Lempinen, S. \& Kaunisto, T. (ed.). Eriarvoistuva maailma - tasa-arvoistava koulu? Kasvatusalan tutkimuksia 78, 145-178. Suomen kasvatustieteellinen seura, Helsinki.

VRN, Valtion ravitsemusneuvottelukunta (2014) Terveyttä ruoasta - Suomalaiset ravitsemussuositukset 2014. Valtion ravitsemusneuvottelukunta, Tampere. 
VRN, Valtion ravitsemusneuvottelukunta (2017) Syödään ja opitaan ybdessä - kouluruokailusuositus. Valtion ravitsemusneuvottelukunta. Terveyden ja hyvinvoinnin laitos, Helsinki.

Wahlen, S., Heiskanen, E. \& Aalto, K. (2012) Endorsing Sustainable Food Consumption: Prospects from Public Catering. Journal of Consumer Policy 35 7-21. https://doi.org/10.1007/s10603-011-9183-4

Warde, A. (2016) Practice of Eating. Polity, Cambridge.

Whitehead, A.N. (1933) The Adventures of Ideas. Macmillan, New York.

Wittmayer, J.M., Schäpke, N. (2014) Action, research and participation: roles of researchers in sustainability transitions. Sustainability Science 9 483-496. https://doi.org/10.1007/s11625-014-0258-4

Miikkulainen, L., Autio, R. \& STT (2018) Puolustusministeri kimpaantui armeija kasvislinjasta: "Ideologista pakkotuputusta ei tarvita" - Pyytää kasvisruoasta selvityksen. Yle Uutiset 24.8.2018. < bttps://yle.fi/ untiset/3-10368100 10.11.2018>

YM, Ympäristöministeriö, 2017. Valtioneuvoston selonteko keskipitkeän aikeavälin ilmastopolitiikan suunnitelmasta vuoteen 2030 - Kobti ilmastoviisasta arkea. Ympäristöministeriö, Helsinki. 